\title{
The Impact of Noninterest Income on the Profitability of Commercial Banks in VietNam: Evidence of Non-Linear Relationship
}

\author{
Khanh Ngoc Nguyen ${ }^{1}$ \\ ${ }^{1}$ Banking Academy, Ha Noi, Vietnam \\ Correspondence: Nguyen Ngoc Khanh, Banking Academy, 12 Chua Boc Street, Quang Trung Ward, Dong Da \\ District, Hanoi 10000, Vietnam. Tel: 84-819-978-668. E-mail: khanhnguyensaxion@ gmail.com
}

Received: October 8, 2020

Accepted: November 18, 2020

Online Published: December 25, 2020

doi:10.5539/ijef.v13n1p100

URL: https://doi.org/10.5539/ijef.v13n1p100

\begin{abstract}
This paper uses the Generalized Method Of Moments (GMM) to analyze the impact of noninterest income on the profitability of 28 Vietnamese commercial banks in the period from 2010 to 2018. At the same time, the Threshold Regression Model is applied on a panel data to evaluate whether or not there is a non-linear relationship between the noninterest income ratio and bank's profitability. The results have shown that the optimal diversification benefit can be attained by reaching a certain level of non-interest income proportion. The findings of the study are: (1) The existence of two thresholds shows that there is non-linear relationship, confirming the non-linear relationship between the noninterest income ratio (NII) and profitability (ROA); (2) The noninterest income ratio impacts negatively on profitability (ROA) when NII $(\leq 44.16 \%$ and $\geq 46.62 \%)$, when the noninterest income ratio is between $44.16 \%$ and $46.12 \%$ the relationship is positive. The noninterest income ratio ranging from $44.16 \%$ to $46.62 \%$ is called optimal when this ratio is in a positive correlation with profitability, which means that Vietnamese commercial banks can try to increase their profits by increasing NII and maintaining that level to get exploiting their maximum level of diversification from noncredit income.
\end{abstract}

Keywords: noninterest income, bank performance, threshold regression model; nonlinear relationship, Vietnamese commercial banks

\section{Introduction}

Over the last two decades, the banking industry has changed structurally because of reduction of financial regulation and a rapid increase in information, communication, and technology in the financial markets. These competitive pressures have resulted in lower net interest margins and weak profitability, with many banks changing their business model by pursuing new banking activities. Noninterest income has become a legitimate activity of banks; indeed, according to DeYoung and Rice (2003), such income now makes up $40 \%$ of all operating income in the commercial banking industry of the United States. More and more banks are dependent on non-interest income to increase revenue and profit (Bian et al., 2015). The Vietnam banking system is also working to increase its proportion of noninterest income, but its ability to do so is relatively undeveloped. Noncredit activities like payment, investment, trading on foreign exchanges, and financial counseling, as well new modern banking products, are underdeveloped or still being tested. Yet as the state bank tightens currency, traditional banking operations are no longer a source of high income for the banks. They have no choice but to increase the proportion of noninterest income to interest income and to find new products and services that can generate income. The invasion of the domestic market by foreign banks has also increased competitive pressure on Vietnamese banks.

Noncredit services are fee-based services that do not involve offering the credit that a lending institution typically offers to customers. By providing significant revenue for banks, income from noncredit services can limit the erosion of profitability when net interest margins are squeezed by declining interest rates. The increasing proportion of noninterest income reflects the banks' diversification into noncredit products and services (Tien \& Hien, 2014). Many studies of the growth of noninterest income have measured the effect of noninterest activities on bank's performance. DeYoung and Rice (2003) and Bian et al. (2015) concluded that increasing the noninterest income of commercial banks enhances performance. Some research suggests that noncredit activity and better risk adjustment can improve the efficiency and profits of banks (Pennathur et al., 2012; Sanya \& Wolfe, 2011). Studying the banks of 29 Asia Pacific countries, Lee et al. (2014) demonstrated a 
positive relationship between income diversification and profitability of the bank.

On the other hand, other studies have shown that expanding this kind of income can hurt performance. For example, Smith et al. (2003) argued that an increase in noninterest income cannot fully offset losses of income from other sources. Moreover, some studies have shown that noninterest income and bank's performance found to have a negatively correlated and the instability of noninterest income can reduce profitability. Maudos and Solís (2009) highlighted the negative relationship between noninterest income and the net profit of Mexican banks. Bilal et al. (2020) indicate that there is a negative association of net noninterest income with bank margin. $\mathrm{He}$ and $\mathrm{Xu}(2010)$ analyzed the condition and structure of the noninterest income of China's commercial banks from several angles, using data from 2005 to 2009 of ten banks. The article concludes that noninterest income has had an important impact on the profitability of banks and proposes a strategy of promoting further development of noninterest income. In Vietnam, research investigating the effects of diversification on bank performance and stability has increased in both quantity and quality, especially in terms of the quality of the research methodology.. Despite this, the number of studies on the impact of noncredit earnings on the business performance of commercial banks is limited. Most of the researchers' viewpoints support the increase in noninterest income, which will have a positive impact on the performance of commercial banks in Vietnam. Typically, there are studies by Minh and Canh (2015) and Hau (2017) showing that non-interest income does not affect risk but has a positive impact on the operation of commercial banks in the research period. Commercial banks have been focused on developing utility and modern banking services, increasing the proportion of noninterest income in total income. This trend is suitable for banking activities in developed economies to minimize risks and ensure the sustainable development of banks. However, there are still challenges and worries that require banks to strengthen urgent solutions in time to increase competitiveness in the market. So far, only a few studies such as Sun et al. (2017) have demonstrated a non-linear relationship between non-credit income and banks' performance; or Noor and Siddiqui (2019) investigating the non-linearity of the relationship between non-interest income of banks in Pakistan and their profitability to exploit the optimal level of non-interest income in the income structure in order to be effective in finding profit from income diversification.

In this study, the author will examine the non-linearity in the relationship between non-interest income on the performance of commercial banks in Vietnam with data from 28 banks in the period 2010-2018.

\section{Literature Review}

Stiroh (2004b) while examining the diversification benefits in US banks from 1984 to 2001, finds noninterest income to be remarkably volatile and correlated with net interest income; banks relying heavily on noninterest income show also lower risk-adjusted profitability. Stiroh concluded that a greater reliance on noninterest income, particularly trading revenue, was associated with higher volatility and lower risk-adjusted profit in a cross-section of the bank. Craigwell and Maxwell (2006) studied the determinants of noninterest income and its impact on commercial bank financial performance. The authors have used data from a sample of Barbados banks for the period 1985 to 2001 . Their results indicate that noninterest income is positively related to both bank profitability and earnings volatility. Mercieca et al. (2007) reported that small European banks do not benefit from diversification. Higher noninterest income will lead to lower profits, increase risk and reduce risk-adjusted profits. Moreover, trading activities are risky and unprofitable. According to Lepetit et al. (2008) banks with a high reliance on non-profit activities are at a higher risk of default than banks that mainly provide loans and show the positive correlation that they found between noninterest income and risk is mostly accurate for small banks.

Sanya and Wolfe (2011) highlight the benefits of revenue diversification for developing countries. In a cross-country study conducted for a sample of listed banks from 11 emerging countries, they found that revenue diversification and profitability are positively related, diversification between interest and noninterest activities also increase profitability and reduce risks for banks. Saunders et al. (2016) found that banks that diversify away from interest income to noninterest income have lower insolvency risk but higher profitability. Nguyen (2012) also highlighted the benefits of income diversification in countries in Southeast Asia. Their results show that banks with strong market power can minimize the risk of diversification into noncredit activities. Maudos and Solís (2009) highlight the existence of a negative relationship between banks' interest margin and noninterest income in Mexico banks. Sawada (2013) argued that both fee income and transaction income have a significant positive impact on the Banks' business performance.

Meslier et al. (2014) used a unique dataset of Philippines' banks and found that moving towards noninterest activities increases bank risk-adjusted profits particularly when banks are more involved dealing in government securities. Li and Zhang (2013) used Chinese banks data over the period 1986-2008, showed that noninterest 
income has a positive impact on the revenue of the banks, but it simultaneously increased the risks. Based on the data from 29 Asia-Pacific countries Lee et al. (2014) also analyzed the effectiveness of the banks' increase in noninterest income. The authors provided evidence of the positive impact of noninterest income on the countries with outstanding banking and financial systems. Using US banks' data, Saunders et al. (2014) established that bank revenue diversification causes higher profits and less insolvency risk. Köhler (2015) assesses the role and importance of diversification for noninterest income of banks at national and international levels. Research results show that noninterest income has a positive impact on the profitability of commercial banks. Ahamed (2017) which has considered commercial Banks in India for the period 1998 to 2014, found that income diversification resulted in higher risk-adjusted profitability (stability) for these banks.

Sun et al. (2017) have used a dataset of 16 listed Chinese commercial banks, over the period of 2007 to 2013 to test the effect of noninterest income on bank performance. By performing a panel threshold model, empirical findings indicate that there is a nonlinear relationship between noninterest income and bank performance (U-shaped chart). The authors reported that noninterest income increases the Banks' business efficiency to a certain extent will not yield a profit to the bank anymore. Noor and Siddiqui (2019) investigate the non-linearity in the relationship between Noninterest Income for banks in Pakistan and their profitability to exploit the optimal level of noninterest income ratio in order to diversify income profitably. The research suggests that banks can get the maximum benefit from a non-traditional source of income if they strive to take the proportion of their noninterest income up to a certain level especially in regimes of low-interest income when the low-interest margins can substantially affect profitability. Park et al. (2019) analyzed the impact of noninterest income on the risks and profits of US banks in the 2007-2009 financial crisis. The research results show that noninterest income has a positive impact on banking risks and profits during the crisis.

Minh and Thanh (2020) and Hau (2017) show that noninterest income that is correlated with financial performance and the risk-adjustment performance of the bank if income is increased from service activities, transactions, investments, the ability to profit will increase. Minh Sang (2017) pointed out that noninterest income has no impact on risks but has a positive impact on the profitability of commercial banks. Park et al. (2019) analyzed the impact of noninterest income on the risks and profits of US banks in the 2007-2009 financial crisis. The research results show that noninterest income has a positive impact on banking risks and profits during the crisis.

Many experimental international studies analyze the impact of noninterest income on banking operations such as Stiroh (2004b); Craigwell and Maxwell (2006); Saunders et al. (2014); Park et al. (2019) studying banks in the US; Maudos and Solís (2009) analyzing the banks in Mexico; Study the Chinese banks as research of Li and Zhang (2013); Sun et al. (2017). Meanwhile, Mercieca et al. (2007), Sanya and Wolfe (2011), Nguyen (2012), Sawada (2013), Lee et al. (2014), Meslier et al. (2014), Köhler (2015) are cross-country or geographic area studies. Despite studies with research spaces, the timing of the study, as well as the use of models with different variables, the overall point of the study, is approaching according to the different angles of the income diversification model, emphasizing the importance of converting the income structure from traditional credit activities to non-credit activities. So far, only Sun et al. (2017) demonstrate the nonlinear relationship between noninterest income and bank performance. Noor and Siddiqui (2019) investigated the non-linearity of the relationship between noninterest income for commercial banks in Pakistan and their profitability to exploit the optimal level of the noninterest rate to optimize the effective diversification of income yields the highest returns. The research shows that that banks can get maximum benefit from a non-traditional source of income if they try to take the their noninterest rate income up to a certain level, especially in regimes of lowinterest income when the low-interest margins can substantially affect the profitability. In Viet Nam, the research on the influence of diversification to operational efficiency and stable bank increasing in quantity, quality as well as methods, the direction of approach to research. However, the number of studies on the impact of noninterest income on the business operations of commercial banks is limited.

\section{Research Methodology}

\subsection{Data Description}

The study used both descriptive and inferential analysis techniques for analyzing the data collecte. In the study, the data were collected from the audited financial statements and annual reports of 28 commercial banks in Vietnam in the period of 2010-2018. The researcher selected banks owning full financial statements. In addition, data were also collected from the State Bank of Vietnam, General Statistics Office of Vietnam, Ministry of Finance and websites of banks... Data was processed through Stata 13 software by cleaning and analysis tool. 


\subsection{Model Specification}

Many empirical studies approaching different directions have been conducted on domestic and transnational banks to analyze the impact of noninterest income on the banks' performance. Some studies suggest that noninterest activities can improve banking performance and profit-adjusted profits (Sanya \& Wolfe, 2011); Meslier et al. (2014); Lee et al. (2014)). Sun et al. (2017) demonstrate the nonlinear relationship between noninterest income and bank performance.

This study applied a dynamic panel data approach proposed by Arellano and Bover (1995) and Blundell and Bond (2000) used GMM modeling techniques to solve endogenous problems, variance and autocorrelation. With the foundation of theoretical studies and empirical studies, like Stiroh (2004a), Mercieca et al. (2007), Lepetit et al. (2008), Chiorazzo et al. (2008), Lee et al. (2014). The estimation model is as follows:

$$
\text { Performance }(R O A)_{i, t}=\alpha_{i, t}+\beta_{1} N I I+\sum_{s=2}^{6} \beta_{s} \lambda_{i, t}+\varepsilon_{i, t}
$$

Among these: $i$ represents the number of banks, $i=1 \ldots 28$; $\mathrm{t}$ denoted time $(\mathrm{t}=2010-2018), \beta$ represents the regression coefficient; $\lambda$ indicates the control variable matrix; $\varepsilon$ is the error. Measuring performance by ROA; NII is measured by the noninterest income. Control variables include: loan outstanding balance/asset ratio; equity/asset ratio; non-performing loan/loan outstanding balance ratio; asset growth; liquidity ratio (see Table 1).

The paper estimates the regression parameter for modeling the factors that impact with fixed effects model (FEM) and random effects model (REM), and GMM for the best equation that shows the relationships of the factors. Arellano and Bover (1995), Blundell and Bond (2000) have proposed a system GMM estimation tool to solve problems with differential GMM. The Hansen index (1982) is used to check the validity of instrument variables. Testing standards using t statistics and corresponding p-value, reliability is based on 95\%, the p-value will be directly compared with 0.05 to conclude to approve or reject the research hypothesis.

Data used in this study is a panel data, the large sample size is suitable for threshold regression analysis (Hansen, 1999). The model of this research is based on Hansen's Panel threshold model to determine the association of noninterest income and profitability of banks. Hansen (1999) argues that the endogenous variable in the model is the proposed variable to evaluate the threshold value to change its effect (nonlinear relationship) on the dependent variable in the threshold regression model. The model for this research is proposed as follows:

$$
\text { Performance }(R O A)_{i, t}=\alpha_{i, t}+\beta_{1} N I I\left(q_{i, t} \leq \gamma\right)+\beta_{2} N I I\left(q_{i, t}>\gamma\right)+\sum_{s=3}^{7} \beta_{s} \lambda_{i, t}+\varepsilon_{i, t}
$$

In this case, the association of non-interest income ratio (NII) and profitability (ROA) of banks is to be found when NII $(\leq \gamma)$ and NII $(>\gamma)$. The data used in this paper has multiple individuals (banks) observed over multiple years so the model applied is Panel Threshold Model. This will help in capturing the effect of the threshold which is the state in which the proposed variables affect the dependent variable in a way and after crossing that value (threshold point) the association changes into another.

Table 1. Research variables

\begin{tabular}{cccc}
\hline Classification & Variable & Definition & Source \\
\hline Dependent variables & ROA & Returns on assets & (Chiorazzo et al., 2008); Stiroh (2004a); (Stiroh, 2004b) \\
Independent variables & NII & Non- interest income/ Total income & Stiroh (2004b), Stiroh và Rumble (2006), Chiorazzo et al. \\
& SIZE & Natural logarithm of total assets & (2008) \\
& LTA & Ratio of loans to total assets & Curi et al. (2015) Vallascas \& Keasey (2012) \\
Control variable & ETA & Equity To Assets & Sanya \& Wolfe (2011), Chiorazzo et al. (2008) \\
& NPL & Non -performing loan/loan outstanding balance & Porter \& Chiou (2013) \\
& GTA & Growth rate of total assets & Aggarwal \& Jacques (2001); \\
& LIQ & Liquidity ratio = loan outstanding & (Chiorazzo et al., 2008); Stiroh (2004b) \\
& balance/customer deposits & (Demirgüç-Kunt \& Huizinga, 2010); (Norden \& Weber, \\
\hline
\end{tabular}

Source: Summary of the author.

\section{Results and Discussion}

\subsection{Descriptive Statistics}

This study aims to assess the impact of noninterest income on performance of 28 Vietnamese commercial banks in the period of 2010-2018. Table 2, descriptive statistics of research variables, including dependent variables, independent variables used in the GMM (Generalized Method of Moments) system model. Statistical results show that banks' ROA use efficiency is approximately $0.7 \%$ on average. Meanwhile, noninterest income 
accounts for only $20.28 \%$ of the total average income of banks. This is a new challenge for Vietnamese banking system in the context of digital economy develop. Loan outstanding balance accounts on average of $53.6 \%$ of total loan outstanding balance, the liquidity ratio reaches 0.851 . Non-performing loan ratio of commercial banks is $2.5 \%$ on average; Equity/asset ratio reaches $9.26 \%$, ensuring compliance with the regulations of the State Bank of Vietnam and satisfying Basel II standards.

Table 2. Summary descriptive statistics

\begin{tabular}{|c|c|c|c|c|c|}
\hline VARIABLE & Obs & Mean & SD & Min & Max \\
\hline \multicolumn{6}{|c|}{ Bank performance } \\
\hline ROA & 252 & 0.0072 & 0.0065 & -0.0551 & 0.0264 \\
\hline \multicolumn{6}{|c|}{ Independent variables } \\
\hline NII & 252 & 0.2028 & 0.2144 & -0.4435 & 1.1016 \\
\hline \multicolumn{6}{|c|}{ Control variable } \\
\hline LTA & 252 & 0.5282 & 0.1383 & 0.1448 & 0.7859 \\
\hline LIQ & 252 & 0.1533 & 0.0966 & 0.0075 & 0.5671 \\
\hline ETA & 252 & 0.0906 & 0.0375 & 0.0231 & 0.2554 \\
\hline NPL & 252 & 0.0248 & 0.0158 & 0.0001 & 0.1140 \\
\hline GTA & 252 & 0.2262 & 0.2843 & -0.6208 & 1.6484 \\
\hline
\end{tabular}

Source: The authors' calculation from annual reports of 28 Vietnamese commercial banks in the period of 2010-2018.

\subsection{The Impact of Noninterest Income on the Performance of Commercial Banks}

In order to solve the research problems, the paper conducts regression of panel data with fixed effects model and random effects model. Arellano and Bover (1995), (Blundell \& Bond, 1998, 2000) have proposed a system GMM estimation tool to solve problems with differential GMM. The Hansen index (1982) is used to check the validity of instrument variables. The study first conducted a correlation analysis to detect autocorrelation and partially identify multidimensional defects of independent variables affecting regression models. The results show that there is no autocorrelation, multicollinearity is not a serious problem affecting the estimation results of the regression model (Gujarati et al., 2004). Multicollinearity does not reduce the predictive power or reliability of the model, facilitating the implementation of subsequent verification steps.

Next, the study used estimation of system GMM (sys-GMM) to solve endogenous phenomena in dynamic table data model in a short and unbalanced period. Check the appropriateness of estimating system GMM by AR (2) and Hansen (1982). The results of the study show that these tests are not statistically significant, meaning that the system GMM model is suitable because there is not second-order autocorrelation and variables are appropriate. Research results are shown in Table 3.

Table 3. The impact of noninterest income on bank's profitability (GMM model)

\begin{tabular}{|c|c|c|c|c|}
\hline \multirow{2}{*}{ VARIABLE } & \multicolumn{4}{|c|}{ ROA } \\
\hline & FE & RE & GMM & GMM system \\
\hline \multirow[t]{2}{*}{$\overline{\text { ETA }}$} & $0.0451^{* * *}$ & $0.0423^{* * *}$ & 0.0645 & $0.0435 * * *$ \\
\hline & {$[3.74]$} & [3.77] & [1.49] & [3.09] \\
\hline \multirow[t]{2}{*}{ NPL } & $0.0482 * *$ & 0.0216 & -0.046 & 0.0212 \\
\hline & {$[2.01]$} & {$[0.91]$} & {$[-0.53]$} & [0.99] \\
\hline \multirow[t]{2}{*}{ NII } & $-0.0107 * * *$ & $-0.00689 * * *$ & $-0.00712 *$ & $-0.00584 * *$ \\
\hline & {$[-4.61]$} & {$[-3.41]$} & {$[-1.91]$} & {$[-2.28]$} \\
\hline \multirow[t]{2}{*}{ LTA } & 0.000327 & 0.00399 & -0.0135 & 0.00424 \\
\hline & {$[0.08]$} & [1.10] & {$[-1.06]$} & {$[0.98]$} \\
\hline \multirow[t]{2}{*}{ GTA } & $0.00404 * * *$ & $0.00411^{* * *}$ & -0.00292 & $0.00204 *$ \\
\hline & [3.13] & [3.11] & {$[-0.58]$} & {$[1.72]$} \\
\hline \multirow[t]{2}{*}{ LIQ } & $0.0104 * * *$ & $0.00752^{* * * *}$ & $0.0345 * * *$ & $0.00543 * * *$ \\
\hline & {$[4.42]$} & [3.32] & [3.15] & {$[4.01]$} \\
\hline \multirow[t]{2}{*}{ Constant } & $-0.00584 * *$ & $-0.00523^{* *}$ & & -0.00413 \\
\hline & {$[-2.07]$} & {$[-2.05]$} & & {$[-1.60]$} \\
\hline $\mathrm{N}$ & 252 & 252 & 224 & 252 \\
\hline R-sq & 0.288 & 0.5171 & & \\
\hline $\mathrm{AR}(2)$ & & & -0.79 & -1.66 \\
\hline Sargan & & & 13.6 & 21.92 \\
\hline Hansen & & & & 15.07 \\
\hline
\end{tabular}

Note. $* * *, * *, *$ represent significance at the $1 \%, 5 \%$ and $10 \%$ levels, respectively. 
The research results indicates that noninterest income nagatively affects the performance of the Vietnamese banking system measured by ROA. This result is in agreement with the study of Maudos and Solís (2009) when highlighting a negative relationship between non-credit income and net profit for Mexican banks; $\mathrm{He}$ and $\mathrm{Xu}$ (2010) analyzed the status and structure of the noninterest income of China's commercial banks, concluding that noninterest income has a very important effect, there is a negative correlation between the noninterest income ratio and profitability.

Chiorazzo et al. (2008) argue that the relationship between noninterest income and bank performance is inconsistent with the results of US and European banking studies due to differences in structure, size, and regulation between these markets. In this study, the results also showed a contrast to the regression results of the relationship between noninterest income and profitability of most US banking studies. This stems come from two main differences between the income structure of the Vietnamese banking system and that of the US: Firstly, the difference in the correlation between the growth rate of net interest income and income from non-credit activities; secondly is the difference in the distribution of components of noninterest income. Stiroh (2004a) also finds that the correlation between interest income and noninterest income in US banks from 1984 to 2001, this implies that when the banking industry shifts to noninterest revenue, it will bring fewer diversification benefits. However, In Vietnam, the correlation between the growth rates of interest income and noninterest income is weak. Therefore, the weak correlation between them can lead to positive or negative impacts of a shift towards noninterest income on bank's profitability. Data statistics show a significant differences in the distribution of noninterest income between banks in the Vietnamese and the U.S. Stiroh (2004a), showed that in the U.S, the average Banks' fees and other income represent $27 \%$ of net operating income while trading income counts for about only $3.5 \%$. In the same context, the ratio of non interest income moved from $25 \%$ to over $40 \%$ of their aggregate income over the period 1984 to DeYoung and Roland (2001). In the case of the Vietnamese commercial banks, fee and other income counted for $11.56 \%$ of operating income, the average trading income counted for $8.7 \%$.

Next, the study will evaluate whether or not there is a non-linear relationship between the rate of noninterest income and the performance of commercial banks in Vietnam in the period 2010-2018. Research by Hansen (1999) states that the endogenous variable in the model is the proposed variable to evaluate the threshold value to change its effect (nonlinear relationship) on the dependent variable in the threshold regression model. The bootstrapping of $\mathrm{N}=1000$ replicates is conducted and the model estimated the threshold effects for single double and triple along with their significance presented by P-value and F-statistics. The P-value must satisfy the levels statistical significance (p-value less than $\alpha=0.01 * * *$ or $0.05 * *$ or $0.1 *$ ). This test determines the existence of threshold points for NII in the model if there does any. The author consider that, as the noninterest income rate changes, there may be up to three structural change points (thresholds) between noninterest income and the performance. This study estimate the models, and test for existence of change points using the statistic and the associated value derived from 1000 bootstrap replications.

Table 4. Test for existence of Threshold points

\begin{tabular}{lcccccc}
\hline \multirow{2}{*}{ THRESHOLD } & \multicolumn{2}{c}{ ROA } & \multicolumn{2}{c}{ THE FREQUENCY OF } & \multicolumn{3}{c}{ CRITICAL VALUE } \\
\cline { 2 - 3 } \cline { 6 - 8 } & F-statistic & Prob & BOOTSTRAP & $10 \%$ & $5 \%$ & $1 \%$ \\
\hline Single & $37.1^{* * *}$ & 0.003 & 1000 & 166.365 & 201.840 & 286.093 \\
Double & $19.75^{* *}$ & 0.043 & 1000 & 158.578 & 186.093 & 293.464 \\
Triple & 17.07 & 0.499 & 1000 & 356.295 & 427.895 & 602.167 \\
\hline
\end{tabular}

Note. ***, **, *represent significance at the $1 \%, 5 \%$ and $10 \%$ levels, respectively.

From the result in Table 4, it can be seen that the existence of a single and double threshold point are significant up to $1 \%$ and $5 \%$. While triple thresholds is not significant (p-value is greater than $\alpha=0.01^{* * *}$ or $0.05^{* *}$ or $\left.0.1^{*}\right)$.

Table 5. Determine the threshold value of NII

\begin{tabular}{lccccc}
\hline \multirow{2}{*}{ MODEL } & \multicolumn{5}{c}{ ROA } \\
\cline { 2 - 6 } & Threshold & Lower & Upper & Fstat & Prob \\
\hline Th-1 & 0.4536 & 0.4416 & 0.4662 & $37.1 * * *$ & 0.002 \\
Th-21 & 0.4536 & 0.4416 & 0.4662 & $19.75^{* *}$ & 0.035 \\
\hline Note. ***, **, * represent significance at the $1 \%, 5 \%$ and $10 \%$ levels, respectively. & &
\end{tabular}


Table 5 show that the F-test estimates the single and double threshold with statistical significance at the $1 \%$ and $5 \%$ level, so the threshold of the ratio of non-interest income to total income has been determined. A structural change is observed in the relationship between non-credit income ratio and the Banks' business performance when the NII is $44.16 \%$ lower, $41.16 \%-46.62 \%$ and $46.62 \%$ greater.

Table 6. Estimates of double threshold model- the impact of noninterest income on profitability

\begin{tabular}{lc}
\hline VARIABLE & ROA \\
\hline ETA & $0.0462^{* * *}$ \\
& {$[3.23]$} \\
NPL & 0.0155 \\
& {$[0.58]$} \\
LTA & $0.00768^{*}$ \\
& {$[1.78]$} \\
GTA & $0.00633^{* * *}$ \\
& {$[3.35]$} \\
LIQ & $0.00934^{* * *}$ \\
NII $(\leq 44.16 \%)$ & {$[3.72]$} \\
NII $(44.16-46.62 \%)$ & $-0.00922^{*}$ \\
NII $(\geq 46.62 \%)$ & {$[-0.06]$} \\
Constant & $0.492^{* * *}$ \\
& {$[4.86]$} \\
N & $-0.179^{* *}$ \\
R-sq & {$[-2.02]$} \\
represent significance at the $1 \%, 5 \%$ and $10 \%$ levels, respectively. & $-0.0112^{* * *}$ \\
\end{tabular}

Note. $* * *, * * *$ represent significance at the $1 \%, 5 \%$ and $10 \%$ levels, respectively.

The above results show the different relationships of the non interest income ratio with the profitability of banks at the lower and higher the threshold. The study also demonstrates the view that (Sun et al., 2017) exist a non-linear relationship between non-credit income and business performance. Noor and Siddiqui (2019) investigated the non-linearity of the relationship between non-interest income for banks in Pakistan and their profitability to exploit the optimal level of the non-interest rate to optimize the effective diversification of income yields the highest returns. This research shows that banks can get maximum benefit from traditional non-credit income if they strive to increase the proportion of non-credit income to a certain extent. Especially, in the case of net interest income ratio compared to the gross income low because the non-credit income can significantly affect the profitability. Banks should come up with more innovative ways of financial products and services to maximize non-credit income and invest resources effectively. At the same time, carefully monitor to minimize the risks that may cause to this activity.

From Table 6, when add the two threshold values, noninterest income ratio becomes signifcant. And the coefcients are signifcantly different in different threshold interval. When noninterest income ratio is less than $44.16 \%$, the coefcient estimated by threshold model is - 0.06 , which means the return on asset (ROA) is negatively correlated with noninterest income ratio (NII); when the noninterest income ratio is between $44.16 \%$ and $46.62 \%$, the coefcient of noninterest income is 4.48 , but the correlation between ROA and NII turned positive. When noninterest income ratio surpasses the second threshold $46.62 \%$, the coefcient of noninterest income ratio back to negative (it is -2.02).

The noninterest income ratio impacts negatively on profitability (ROA) when NII $(\leq 44.16 \%$ and $\geq 46.62 \%$ ), when the noninterest income ratio is between $44.16 \%$ and $46.12 \%$ the relationship is positive. The noninterest income ratio ranging from $44.16 \%$ to $46.62 \%$ is called optimal when this ratio is in a positive correlation with profitability, which means that Vietnamese commercial banks can try to increase their profits by increasing NII and maintaining that level to get exploiting their maximum level of diversification from noncredit income. Implications of the paper are that the ratio should be controlled in a range or noninterest income will not positively affect the performance, and a high level of performance can be gained only by raising the ratio to a certain level. This result is even more confirmed when the results of the system GMM model show that the 
noninterest income ratio has a negative impact on the banks' performance.

The statistical results also show that the structure of the component income sources in the noninterest income is not reasonable, the current rate of fee income is still low while the proportion of income from transactions and other income is still at a high level. in the context of the commercial banking system still facing many risks, lack of experience in investment, transaction, and product development. Meanwhile, services need to increase a reasonable proportion. Banks need to have solutions to adjust the proportion of fee, maintain a reasonable ratio of transaction and other; appropriate rate structure of fee, transaction, and other in total income is about $22 \%$, $16 \%$, less than $7 \%$, respectively. In Viet Nam, income from banking services is still mainly from card fees, credit card fees, intermediary services of real estate transaction payment, international payment and ATM and internet banking and mobile banking fees. Increasing the proportion of noninterest income in the income structure is one of the strategies to increase profits for banks when the credit growth limit is restricted under the Interest Rate Ceiling regulations. However, the lack of experience in investment as well as a shortage of investment banking functions such as management systems, risk control makes these activities not really effective. In fact, the growth and contribution of service activities to the bank's revenue are not commensurate with the potential; Although there are changes and some positive effects, it is not enough to offset the risk from net interest income.

\section{Check Robust}

The author had tested the robustness of the results by controlling for possible endogeneity, following (Elsas et al., 2010) approach of using lagged instrumental variables. If endogenous variables do not exist, the study will use a two-stage least squares regression (2SLS) estimated .

The results of Table 7 shows that AR (2) and Hansen tests are not statistically significant, which means that the system GMM model has no autocorrelation and tool variables are consistent. (Hausman \& Taylor, 1978; Schultz et al., 2010). Therefore, the research model used in this paper is highly sustainable.

Table 7. Check robustness of regression

\begin{tabular}{lcc}
\hline \multirow{2}{*}{ Variable } & & ROA \\
\cline { 2 - 3 } ETA & GMM & GMM system \\
\cline { 2 - 3 } NPL & $0.0528^{*}$ & 0.0435 \\
& {$[1.98]$} & {$[1.55]$} \\
NII & -0.0223 & 0.0212 \\
& {$[-0.40]$} & {$[0.61]$} \\
LTA & -0.00459 & -0.00584 \\
& {$[-0.75]$} & {$[-0.67]$} \\
GTA & -0.00477 & 0.00424 \\
& {$[-0.61]$} & {$[0.36]$} \\
LIQ & 0.0021 & 0.00204 \\
& {$[0.65]$} & {$[0.85]$} \\
Constant & $0.0221^{* * *}$ & $0.00543 *$ \\
& {$[5.16]$} & {$[1.74]$} \\
N & $-0.0130^{* * *}$ & -0.00413 \\
AR(2) & {$[-3.23]$} & {$[-0.70]$} \\
Sargan & 252 & 252 \\
Hansen & -1.22 & -1.56 \\
\hline
\end{tabular}

Note. ***, **, * represent significance at the $1 \%, 5 \%$ and $10 \%$ levels, respectively.

\section{Conclusions}

Structural changes in the banking industry and the rise of alternative funding sources for enterprises have allowed banks to find different ways to increase profits along with traditional lending operations. From a theoretical point of view, the decision to diversify income sources should increase a bank's efficiency, thanks to economies of scope (Klein \& Saidenberg, 1997). Many studies have been conducted from one country to another one to analyze the impact of noninterest income on the efficiency of banks' performance. Some studies suggest that noninterest income can improve banks' performance. However, there is also a view that does not support the diversification strategy of banks, they argue that the high cost of diversification reduces profits when banks 
invade their amateur activities. This paper uses the generalized method of moments (GMM) to analyze the impact of noninterest income on the performance of 28 Vietnamese commercial banks in the period from 2010 to 2018. GMM modeling uses techniques to deal with endogeneity, variance, and autocorrelation in the research model. Also, use the Threshold Estimate Model to evaluate whether or not there is a nonlinear relationship between the noninterest income and banks' profitability. This study provides evidence of nonlinear relationship between noninterest income and the profitability of banks. This result shows consistency with the research results of Sun et al. (2017) in China, Noor and Siddiqui (2019) in Pakistan. However, the results of this study contradict most studies on the role of noninterest income in the operations of US banks as well as some other developed countries in which most studies have found that when banks develop noninterest services that will increase bank income and have a significant positive effect on performance.

This difference between banks in Vietnam and banks elsewhere stems from differences in the income structure of the Vietnamese banking system and those of developed countries in which noninterest income accounts for a high proportion of total income, even surpassing netinterest income. Banks can maximize the benefit of nontraditional income when they strive to increase their non-credit income ratio to a certain extent. The noninterest income ratio impacts negatively on profitability (ROA) when NII $(\leq 44.16 \%$ and $\geq 46.62 \%)$, when the noninterest income ratio is between $44.16 \%$ and $46.12 \%$ the relationship is positive. The noninterest income ratio ranging from $44.16 \%$ to $46.62 \%$ is called optimal when this ratio is in a positive correlation with profitability, which means that Vietnamese commercial banks can try to increase their profits by increasing NII and maintaining that level to get exploiting their maximum level of diversification from noncredit income. Implications of the paper are that the ratio should be controlled in a range of noninterest income will not positively affect the performance, and a high level of performance can be gained only by raising the ratio to a certain level.

This result is even more confirmed when the results of the system GMM model show that the noninterest income ratio has a negative impact on the banks'performance. Banks should come up with more innovative ways of financial products and services to maximize noninterest income and invest resources effectively. In general, Vietnamese commercial banks in the period of deepening international economic integration have been focusing on the development of modern and convenient banking services, increasing the proportion of noninterest income in total income. This trend in modern banking seems to be suitable only for banking operations in developed economies to minimize risks and ensure the sustainable development of banks. However, in developing countries that still face many challenges, anxieties require banks to strengthen their urgent solutions promptly in order to increase their competitiveness in the marketplace.

\section{References}

Aggarwal, R., \& Jacques, K. T. (2001). The impact of FDICIA and prompt corrective action on bank capital and risk: Estimates using a simultaneous equations model. Journal of Banking \& Finance, 25, 1139-1160. https://doi.org/10.1016/S0378-4266(00)00125-4

Ahamed, M. M. (2017). Asset quality, non-interest income, and bank profitability: Evidence from Indian banks. Economic Modelling, 63, 1-14. https://doi.org/10.1016/j.econmod.2017.01.016

Arellano, M., \& Bover, O. (1995). Another look at the instrumental variable estimation of error-components models. Journal of Econometrics, 68, 29-51. https://doi.org/10.1016/0304-4076(94)01642-D

Bian, W. L., Wang, X. N., \& Sun, Q. X. (2015). Non-interest income, profit, and risk efficiencies: Evidence from commercial banks in China. Asia-Pacific Journal of Financial Studies, 44, 762-782. https://doi.org/10.1111/ajfs.12112

Bilal, S., Noor, M., \& Nadeem Uz, Z. (2020). Diversification, Industry Concentration, and Bank Margins: Empirical Evidence from an Emerging South Asian Economy. The Journal of Asian Finance, Economics and Business, 7, 349-360. https://doi.org/10.13106/jafeb.2020.vol7.no7.349

Blundell, R., \& Bond, S. (1998). Initial conditions and moment restrictions in dynamic panel data models. Journal of econometrics, 87, 115-143. https://doi.org/10.1016/S0304-4076(98)00009-8

Blundell, R., \& Bond, S. (2000). GMM estimation with persistent panel data: an application to production functions. Econometric reviews, 19, 321-340. https://doi.org/10.1080/07474930008800475

Chiorazzo, V., Milani, C., \& Salvini, F. (2008). Income diversification and bank performance: Evidence from Italian banks. Journal of Financial Services Research, 33, 181-203. https://doi.org/10.1007/s10693-008-0029-4 
Craigwell, R., \& Maxwell, C. (2006). Non-interest income and financial performance at commercial banks in Barbados. Savings and Development, 309-328. Retrieved from http://www.jstor.org/stable/25830936

Curi, C., Lozano-Vivas, A., \& Zelenyuk, V. (2015). Foreign bank diversification and efficiency prior to and during the financial crisis: Does one business model fit all? Journal of Banking \& Finance, 61, S22-S35. https://doi.org/10.1016/j.jbankfin.2015.04.019

Demirgüç-Kunt, A., \& Huizinga, H. (2010). Bank activity and funding strategies: The impact on risk and returns. Journal of Financial Economics, 98, 626-650. https://doi.org/10.1016/j.jfineco.2010.06.004

DeYoung, R., \& Rice, T. (2003). Noninterest Income and Financial Performance at US Commercial Banks. Emerging Issues Series, Supervision and Regulation Department, Federal Reserve Bank of Chicago. https://doi.org/10.1111/j.0732-8516.2004.00069.x

DeYoung, R., \& Roland, K. P. (2001). Product mix and earnings volatility at commercial banks: Evidence from a degree of total leverage model. Journal of Financial Intermediation, 10, 54-84. https://doi.org/10.1006/jfin.2000.0305

Elsas, R., Hackethal, A., \& Holzhäuser, M. (2010). The anatomy of bank diversification. Journal of Banking \& Finance, 34, 1274-1287. https://doi.org/10.1016/j.jbankfin.2009.11.024

Gujarati, D. N., Bernier, B., \& Bernier, B. (2004). Econométrie. De Boeck Brussels.

Hansen, B. E. (1999). Threshold effects in non-dynamic panels: Estimation, testing, and inference. Journal of Econometrics, 93, 345-368. https://doi.org/10.1016/S0304-4076(99)00025-1

Hansen, L. P. (1982). Large sample properties of generalized method of moments estimators. Econometrica: Journal of the Econometric Society, 1029-1054. https://doi.org/10.2307/1912775

Hau, Q. (2017). The impact of non-interest income on the performance of Vietnamese commercial banks in the 2006-2016. Banking Technology Review, 13-17.

Hausman, J. A., \& Taylor, W. E. (1978). Econometrica: Journal of the Econometric Society (pp. 1251-1271).

HE, G. S., \& Xu, J. (2010). Non-interest income business and countermeasures for listed commercial banks in China. Research on Financial and Economic Issues, 12. Retrieved from http://en.cnki.com.cn/Article_en/CJFDTotal-CJWT201012015.htm

Klein, P., \& Saidenberg, M. (1997). Diversification. Organisation, and Efficiency: Evidence from Bank Holding Companies, dattiloscritto. https://doi.org/10.2139/ssrn.98653

Köhler, M. (2015). Which banks are more risky? The impact of business models on bank stability. Journal of Financial Stability, 16, 195-212. https://doi.org/10.1016/j.jfs.2014.02.005

Lee, C. C., Yang, S. J., \& Chang, C. H. (2014). Non-interest income, profitability, and risk in banking industry: A cross-country analysis. The North American Journal of Economics and Finance, 27, 48-67. https://doi.org/10.1016/j.najef.2013.11.002

Lepetit, L., Nys, E., Rous, P., \& Tarazi, A. (2008). Bank income structure and risk: An empirical analysis of

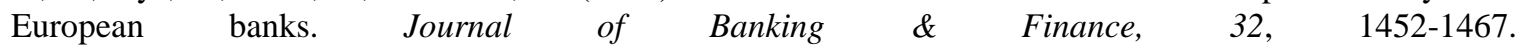
https://doi.org/10.1016/j.jbankfin.2007.12.002

Li, L., \& Zhang, Y. (2013). Are there diversification benefits of increasing noninterest income in the Chinese banking industry? Journal of Empirical Finance, 24, 151-165. https://doi.org/10.1016/j.jempfin.2013.10.004

Maudos, J., \& Solís, L. (2009). The determinants of net interest income in the Mexican banking system: An integrated model. Journal of Banking \& Finance, 33, 1920-1931. https://doi.org/10.1016/j.jbankfin.2009.04.012

Mercieca, S., Schaeck, K., \& Wolfe, S. (2007). Small European banks: Benefits from diversification? Journal of Banking \& Finance, 31, 1975-1998. https://doi.org/10.1016/j.jbankfin.2007.01.004

Meslier, C., Tacneng, R., \& Tarazi, A. (2014). Is bank income diversification beneficial? Evidence from an emerging economy. Journal of International Financial Markets, Institutions and Money, 31, 97-126. https://doi.org/10.1016/j.intfin.2014.03.007

Minh, S. N. (2017). Income diversification and bank efficiency in Vietnam. Journal of Economics and Development, 19, 52. https://doi.org/10.33301/JED.2017.19.03.04 
Minh, \& Canh, N. (2015). Income diversification and factors affecting the profitability of Vietnamese commercial banks. Banking Technology Review, 106, 13-23.

Minh, S., \& Thanh, T. (2020). Analysis of the impact from non-interest income to the operational efficiency of commercial banks in Vietnam. Management Science Letters, 10, 455-462. https://doi.org/10.5267/j.msl.2019.8.025

Nguyen, J. (2012). The relationship between net interest margin and noninterest income using a system estimation approach. Journal of Banking \& Finance, 36, 2429-2437. https://doi.org/10.1016/j.jbankfin.2012.04.017

Noor, I., \& Siddiqui, D. A. (2019). Evidence of Non-Linear Relationship between Non-Interest Income and Profitability of Commercial Banks in Pakistan. Asian Journal of Economic Modelling, 7, 14-26. https://doi.org/10.18488/journal.8.2019.71.14.26

Norden, L., \& Weber, M. (2010). Funding modes of German banks: structural changes and their implications. Journal of Financial Services Research, 38, 69-93. https://doi.org/10.1007/s10693-010-0084-5

Park, B., Park, J., \& Chae, J. (2019). Non-interest income and bank performance during the financial crisis. Applied Economics Letters, 26, 1683-1688. https://doi.org/10.1080/13504851.2019.1591592

Pennathur, A. K., Subrahmanyam, V., \& Vishwasrao, S. (2012). Income diversification and risk: Does ownership matter? An empirical examination of Indian banks. Journal of Banking \& Finance, 36, 2203-2215. https://doi.org/10.1016/j.jbankfin.2012.03.021

Porter, R. L., \& Chiou, W. J. P. (2013). How has capital affected bank risk since implementation of the Basel accords. Banks and Bank System, 1, 1-52.

Sanya, S., \& Wolfe, S. (2011). Can banks in emerging economies benefit from revenue diversification? Journal of Financial Services Research, 40, 79-101. https://doi.org/10.1007/s10693-010-0098-z

Saunders, A., Schmid, M., \& Walter, I. (2014). Non-interest Income and Bank Performance: Is Banks' Increased Reliance on Non-interest Income Bad? School of Finance, University of St. Gallen. https://doi.org/10.2139/ssrn.2504675

Saunders, A., Schmid, M., \& Walter, I. (2016). Non-interest income and bank performance: Does ring-fencing reduce bank risk. Working Papers on Finance,(2014/17), 1417-1477

Sawada, M. (2013). How does the stock market value bank diversification? Empirical evidence from Japanese banks. Pacific-Basin Finance Journal, 25, 40-61. https://doi.org/10.1016/j.pacfin.2013.08.001

Schultz, E. L., Tan, D. T., \& Walsh, K. D. (2010). Endogeneity and the corporate governance-performance relation. Australian Journal of Management, 35, 145-163.https://doi.org/10.1177/0312896210370079

Smith, R., Staikouras, C., \& Wood, G. (2003). Non-interest income and total income stability. https://doi.org/10.2139/ssrn.530687

Stiroh, K. J. (2004a). Diversification in banking: Is noninterest income the answer? Journal of Money, Credit, and Banking, 36, 853-882. https://doi.org/10.1353/mcb.2004.0076

Stiroh, K. J. (2004b). Do community banks benefit from diversification? Journal of Financial Services Research, 25, 135-160.https://doi.org/10.1023/B:FINA.0000020657.59334.76

Sun, L., Wu, S., Zhu, Z., \& Stephenson, A. (2017). Noninterest income and performance of commercial banking in China. Scientific Programming, 2017. https://doi.org/10.1155/2017/4803840

Tien, H. N., \& Hien, V. T. (2014). Discuss the method of calculating the non-credit income ratio of commercial banks. Asian Economics and Banking Journal, 36.

Vallascas, F., \& Keasey, K. (2012). Bank resilience to systemic shocks and the stability of banking systems: Small is beautiful. Journal of International Money and Finance, 31, 1745-1776. https://doi.org/10.1016/j.jimonfin.2012.03.011

\section{Copyrights}

Copyright for this article is retained by the author(s), with first publication rights granted to the journal.

This is an open-access article distributed under the terms and conditions of the Creative Commons Attribution license (http://creativecommons.org/licenses/by/4.0/). 